\title{
REFERENCES
}

Dunlop, D. M. (1963): Eighty-six Cases of Addison's Disease, Brit. med. F., ii, 887.

Felix-Davies, D. (1955): Addison's Disease Presenting as Loss of Weight without Pigmentation, Ibid., 48, 1023. $\frac{\AA}{\Omega}$

Fellows, R. E., Buchanan, J. R., Peterson, R. E., Stokes, P. E. (1962): Chronic Primary Adrenal Insufficierfey without Hyperpigmentation, New Engl. Y. Med., 267, 215.

Jenkins, D., Forsham, P. H., Laidlaw, J. C., ReDDY, W. J., Thorn, G. W. (1955): Use of ACTH in the Diagnoßis of Adrenal Cortical Insufficiency, Amer. F. Med., 18, 3.

Jores, A., TAMM, J. (1959): Uber Einen Fall Von Sogenanntem Weissem M. Addison Mit Cushing-ähnlichem Habifiss

Nach Substitution Mit Prednison, Acta endocr. (Kbh.), 32, 519.
Laidlaw, J. C., RrdDy, W. J., Jenkins, D., HaYdar, N. A., Renold, A. E., Thorn, G. W. (1955): Advances in

Diagnosis of Altered States of Adrenocortical Function, New Engl. F. Med., 253, 747.
LAwson, H. A., BECK, I. A., MurPhy, R. G. (1943): Addison's Disease: Report of a Fatal Case, New Engl. Y. Medd., 228, 480 .

Stone, D. B., Jewel, J. G. (1961): The Danger of Corticotrophin in Addison's Disease, Arch. intern. Med., 107, $3 \overrightarrow{30}^{2}$

Thorn, G. W., Jenkins, D., Laidlaw, J. C., Goetz, F. C., Dingman, J. F., Arons, W. L., Streeten, D. H. P, MCCraCkEN, B. H. (1953): Pharmacological Aspects of Adrenocortical Steroids and ACTH in Man, New Engl.ç. Med., 248, 588 .

Wilks, S. (1862): On Disease of the Supra-renal Capsules or Morbus Addisoni, Guy's Hosp. Rep., 8, I.

\section{ATROPINE POISONING TREATED BY FORCED DIURESI}

\author{
Bernard M. Groden, M.B., M.R.C.P.(Glasg.), M.R.C.P.(Ed.) \\ Medical Unit, Glasgow Royal Infirmary \\ William D. Williams, Ph.D.(Glasg.) \\ Department of Pharmacy, The Royal College of Science and Technology, Glasgow.
}

A THIRTY-ONE-year-old male patient was admitted to hospital three hours after swallowing $7.5 \mathrm{ml}$. of $1 \%$ atropine sulphate eyedrops in a suicidal attempt.

\section{Case Report}

He was found to be hallucinated, irritable, and tremulous. His pupils were widely dilated; muscle tone was increased, with exaggerated reflexes and bilateral ankle clonus. His tongue was dry and furred. His pulse rate was $104 / \mathrm{min}$., blood pressure $140 / 100 \mathrm{~mm}$. Hg. He had not vomited prior to admission to hospital, and had not passed urine.

Treatment. A regime of forced diuresis, similar to that described by Ohlsson (1949) and Lassen (1960) for the treatment of barbiturate intoxication, was initiated. The actual technique was as follows:

Two pints of normal saline were given intravenously in one hour, followed by $0.5 \mathrm{~g}$. chlorothiazide intravenously. Following this, two pints of $5 \%$ dextrose water were given over ninety minutes, and these were followed by $80 \mathrm{~g}$. of urea in $200 \mathrm{ml}$. of water. Subsequently, one pint of $5 \%$ dextrose water was given hourly, and seven hours after starting the treatment a further $0.5 \mathrm{~g}$. of chlorothiazide was given.

All the urine was collected by catheter and the atropine content was estimated by the Vitali Morin reaction. (Appendix, Table I).

Ten hours after commencing treatment the patient was rational and no longer hallucinated. His tremor had disappeared and his reflexes had returned to normal. His pupils, however, remained widely dilated for twenty- four hours, but gradually returned to normal during the subsequent twenty-four hours.

\section{Discussion}

Carter (1940) and Glaister (1957) descri角 patients who have recovered following consumption of similar quantities of atropine. Only symptomatic and supportive treatment have been available, however, and it seems agreed that chemical methođids of treatment are ineffective (Goodman and Gilmą, 1955; Graham, 1962).

Our results indicate that with forced diuresis $25.7 \mathrm{mg}$. of atropine sulphate, that is $34 \%$ of tbe ingested quantity, were excreted in the two houts following commencement of therapy or in the hours after taking the drug. $30.9 \mathrm{mg}$. (4I\% of the ingested dose) were excreted in 10 hours followifos commencement of therapy, that is in the 14 hoyrs after taking the drug. During this period the patient passed $5,800 \mathrm{ml}$. of urine. By comparisor Tonnesen (1950) showed that humans, given doses of 2 to $5 \mathrm{mg}$. of atropine sulphate orally, excreted $\%$ n average $12.7 \%$ of the ingested dose during the new two days.

We were able to detect atropine in the patient's urine for 24 hours after taking the drug, but go atropine could be detected chemically or by the cat's eye test (Sollmann, 1948; Krantz and CaP, 1961) after this. 
TABLE I

Atropine Excretion. (Results expressed as $\left.\left(\mathrm{C}_{17} \mathrm{H}_{23} \mathrm{O}_{3} \mathrm{~N}\right)_{2} \mathrm{H}_{2} \mathrm{SO}_{4}, \mathrm{H}_{2} \mathrm{O}\right)$.

\begin{tabular}{|c|c|c|c|}
\hline $\begin{array}{l}\text { Time after commencement } \\
\text { of diuresis* }\end{array}$ & $\begin{array}{l}\text { Volume of urine } \\
(\mathrm{ml} .)\end{array}$ & $\begin{array}{l}\text { Atropine concentration } \\
\mathrm{mg} . / 100 \mathrm{ml} \text {. }\end{array}$ & $\begin{array}{c}\text { Atropine excreted } \\
\text { mg. }\end{array}$ \\
\hline $\begin{array}{l}\text { Ist hour } \\
\text { 2nd hour } \\
\text { 3rd and 4th hours } \\
5 \text { th and 6th hours } \\
\text { 7th and 8th hours } \\
\text { 9th and roth hours } \\
\text { I ith-14th hours } \\
\text { 1 5th-18th hours }\end{array}$ & $\begin{array}{r}500 \\
1,360 \\
1,400 \\
380 \\
835 \\
1,325 \\
1,490 \\
2,000\end{array}$ & $\begin{array}{c}2.3 \\
1.1 \\
0.2 \\
0.2 \\
0.1 \\
\text { trace } \\
\text { trace } \\
\text { trace }\end{array}$ & \begin{tabular}{r|}
11.3 \\
14.4 \\
2.8 \\
0.8 \\
1.1 \\
0.5 \\
0.2 \\
$<0.1$
\end{tabular} \\
\hline Total & 9,290 & & 3I.I \\
\hline
\end{tabular}

Subsequent specimens were tested chemically and biologically by the cat's eye test but showed no activity in the original solution or in the extracts prepared from them.

* Forced diuresis commenced four hours after ingestion of atropine.

Our results, therefore, are in agreement with the known rapid early excretion of atropine (Tonnesen, 1950). Possible explanations for the rapid fall in the excretion rate are the fixation of atropine in the tissues and the process of detoxication in the liver (Goodman and Gilman, 1955; Beckman, 196r). Although it is difficult to draw a strict comparison between Tonnesen's results and our own because of the difference in the amount of drug ingested, we feel that the quantity of atropine excreted has been significantly increased by producing a substantial diuresis in the early stages of the intoxication.

\section{Summary}

The case is described of a patient who took a large quantity of atropine ( $75 \mathrm{mg}$.) in a suicidal attempt. He recovered rapidly on a regime of forced diuresis. His excretion of atropine was estimated and it was shown that $41 \%$ of the ingested dose was excreted in the ro hours following commencement of treatment, at the end of which time he had recovered from his intoxication apart from continued dilation of the pupils. It is concluded that forced diuresis is of value in the treatment of atropine poisoning.

\section{Appendix: Method of estimating atropine}

Transfer an appropriate volume of urine to a separator and add $2 \mathrm{ml}$. O.I N, $\mathrm{HCl}$ or sufficient to make acid. Dilute, if necessary, to about $50 \mathrm{ml}$. with water and extract with ether ( $50 \mathrm{ml}$.).

Run off the lower aqueous layer into a second separator, wash ether layer with water (Io $\mathrm{ml}$.) and add the washing to the aqueous layer in the second separator.

Make the aqueous layer alkaline with ammonia and extract twice with ether $(50,40 \mathrm{ml}$.). Wash the bulked ether extracts with water $(2 \times 5 \mathrm{ml}$.), transfer the ether to a flask and evaporate to small volume (about $5 \mathrm{ml}$.). Transfer the concentrated ether quantitatively to an evaporating basin and evaporate to dryness.

Add $0.3 \mathrm{ml}$. fuming nitric acid to the residue and evaporate once more to dryness. Cool the basin and add dimethylformamide (cf. Freeman, 1955) (5.00 $\mathrm{ml}$.) and ethanolic potassium hydroxide $(0.5 \mathrm{~N}, 0.50 \mathrm{ml}$.). Compare the colour produced immediately with a blank of distilled water at $560 \mathrm{~m} \mu$. Subtract the reading for a blank on normal urine and read off the amount of atropine from a curve obtained by treating known amounts of atropine sulphate with fuming nitric acid and continuing as described above from the words 'evaporate once more to dryness. ...'

We would like to thank Mr. J. L. Paterson, Department of Pharmacy, the Royal College of Science and Technology, for performing the biological tests, and Dr. Alexander Brown for permission to publish the case report, and for helpful advice.

\section{REFERENCES}

Beckman, H. (196r): 'Pharmacology', 2nd Edition, p. 415. Philadelphia: W. B. Saunders.

CARTER, A. B. (1940): 'Atropine Poisoning-Description of an unusual case.' Brit. med. J., I, 664.

Freeman, F. M. (1955): 'The Analyst', 80, 520.

GLAISTER, J. (1957): 'Medical Jurisprudence and Toxicology', roth Edition, p. 621. Edinburgh: E. \& S. Livingstone.

Goodman, L. S., and Gilman, A. (1955): 'The Pharmacological Basis of Therapeutics', 2nd Edition, pp. $551-553$. New York: Macmillan.

Graham, J. D. P. (1962): 'Diagnosis and Treatment of Acute Poisoning', p. 326. London: Oxford University Press

Krantz, J. C., and CARR, C. J. (196r): 'The Pharmacologic Principles of Medical Practice', 5th Edition, p. 931. London: Baillière, Tindall \& Cox.

LASSEN, N. A. (1960): 'Treatment of Severe Acute Barbiturate Poisoning by Forced Diuresis and Alkalinisation of the Urine', Lancet, 2, 338.

Ohlsson, W. T. L. (1949): 'Blodskoljningsbehandling Vid Svar Barbiturat Forgiftning', Nord. Med., 42, 147 I.

SollmanN, T. (1948): ‘A Manual of Pharmacology and its applications to Therapeutics and Toxicology', 7 th Edition, p. 319. Philadelphia: W. B. Saunders.

Tonneson, M. (1950): 'The Excretion of Atropine and Allied Alkaloids in Urine', Acta. Pharmacol. (Kbh.), 6, 147. 